\title{
Intervention effects of five cations and their correction on hemolytic activity of tentacle extract from the jellyfish Cyanea capillata
}

\author{
Hui Zhang ${ }^{1}$, Qianqian Wang ${ }^{1}$, Liang Xiao ${ }^{\text {Corresp.., }}{ }^{1}$, Liming Zhang ${ }^{\text {Corresp. } 1}$ \\ ${ }^{1}$ Department of Marine Biotechnology, Faculty of Naval Medicine, Second Military Medical University, Shanghai, China \\ Corresponding Authors: Liang Xiao, Liming Zhang \\ Email address: hormat830713@hotmail.com, Imzhang@smmu.edu.cn
}

Cations have generally been reported to prevent jellyfish venom-induced hemolysis through multiple mechanisms by spectrophotometry. Little attention has been paid to the potential interaction between cations and hemoglobin, potentially influencing the antagonistic effect of cations. Here, we explored the effects of five reported cations, $\mathrm{La}^{3+}$, $\mathrm{Mn}^{2+}, \mathrm{Zn}^{2+}, \mathrm{Cu}^{2+}$ and $\mathrm{Fe}^{2+}$, on a hemolytic test system and the absorbance of hemoglobin, which was further used to measure their effects on the hemolysis of tentacle extract (TE) from the jellyfish Cyanea capillata. All the cations displayed significant dose-dependent inhibitory effects on TE-induced hemolysis with various dissociation equilibrium constant $\left(K_{\mathrm{d}}\right)$ values as follows: $\mathrm{La}^{3+} 1.5 \mathrm{mM}, \mathrm{Mn}^{2+} 93.2 \mathrm{mM}, \mathrm{Zn}^{2+} 38.6 \mathrm{mM}, \mathrm{Cu}^{2+} 71.9 \mu \mathrm{M}$ and $\mathrm{Fe}^{2+}$ $32.8 \mathrm{mM}$. The transparent non-selective pore blocker $\mathrm{La}^{3+}$ did not affect the absorbance of hemoglobin, while $\mathrm{Mn}^{2+}$ reduced it slightly. Other cations, including $\mathrm{Zn}^{2+}, \mathrm{Cu}^{2+}$ and $\mathrm{Fe}^{2+}$, greatly decreased the absorbance with $K_{d}$ values of $35.9 \mathrm{mM}, 77.5 \mathrm{mM}$ and $17.6 \mathrm{mM}$, respectively. After correction, the inhibitory $K_{d}$ values were $1.4 \mathrm{mM}, 45.8 \mathrm{mM}, 128.5 \mu \mathrm{M}$ and $53.1 \mathrm{mM}$ for $\mathrm{La}^{3+}, \mathrm{Zn}^{2+}, \mathrm{Cu}^{2+}$ and $\mathrm{Fe}^{2+}$, respectively. $\mathrm{Mn}^{2+}$ did not inhibit TE-induced hemolysis. Moreover, the inhibitory extent at the maximal given dose of all cations except $\mathrm{La}^{3+}$ was also diminished. These corrected results from spectrophotometry were further confirmed by direct erythrocyte counting under microscopy. Our results indicate that the cations, except for $\mathrm{La}^{3+}$, can interfere with the absorbance of hemoglobin, which should be corrected when their inhibitory effects on hemolysis by jellyfish venoms are examined. The variation in the inhibitory effects of cations suggests that the hemolysis by jellyfish venom is mainly attributed to the formation of non-selective cation pore complexes over other potential mechanisms, such as phospholipases A2 (PLA2), polypeptides, protease and oxidation. Blocking the pore-forming complexes may be a primary strategy to improve the in vivo damage and mortality from jellyfish stings due to hemolytic toxicity. 


\section{Intervention effects of five cations and their correction on the}

\section{2 hemolytic activity of tentacle extract from the jellyfish Cyanea}

3 capillata

4 Hui Zhanga, , Qianqian Wanga, , Liang Xiao ${ }^{\mathrm{a}, ~}$, Liming Zhang, *

5 a Department of Marine Biotechnology, Faculty of Naval Medicine, Second Military Medical University,

6 Shanghai, China

7

8 Abstract

9 Cations have generally been reported to prevent jellyfish venom-induced hemolysis through multiple

10 mechanisms by spectrophotometry. Little attention has been paid to the potential interaction between

11 cations and hemoglobin, potentially influencing the antagonistic effect of cations. Here, we explored the

12 effects of five reported cations, $\mathrm{La}^{3+}, \mathrm{Mn}^{2+}, \mathrm{Zn}^{2+}, \mathrm{Cu}^{2+}$ and $\mathrm{Fe}^{2+}$, on a hemolytic test system and the

13 absorbance of hemoglobin, which was further used to measure their effects on the hemolysis of tentacle

14 extract (TE) from the jellyfish Cyanea capillata. All the cations displayed significant dose-dependent inhibitory effects on TE-induced hemolysis with various dissociation equilibrium constant $\left(K_{\mathrm{d}}\right)$ values as follows: $\mathrm{La}^{3+} 1.5 \mathrm{mM}, \mathrm{Mn}^{2+} 93.2 \mathrm{mM}, \mathrm{Zn}^{2+} 38.6 \mathrm{mM}, \mathrm{Cu}^{2+} 71.9 \mu \mathrm{M}$ and $\mathrm{Fe}^{2+} 32.8 \mathrm{mM}$. The transparent non-selective pore blocker $\mathrm{La}^{3+}$ did not affect the absorbance of hemoglobin, while $\mathrm{Mn}^{2+}$ reduced it slightly. Other cations, including $\mathrm{Zn}^{2+}, \mathrm{Cu}^{2+}$ and $\mathrm{Fe}^{2+}$, greatly decreased the absorbance with $K_{\mathrm{d}}$ values of $35.9 \mathrm{mM}, 77.5 \mathrm{mM}$ and $17.6 \mathrm{mM}$, respectively. After correction, the inhibitory $K_{\mathrm{d}}$ values were $1.4 \mathrm{mM}$, $45.8 \mathrm{mM}, 128.5 \mu \mathrm{M}$ and $53.1 \mathrm{mM}$ for $\mathrm{La}^{3+}, \mathrm{Zn}^{2+}, \mathrm{Cu}^{2+}$ and $\mathrm{Fe}^{2+}$, respectively. $\mathrm{Mn}^{2+}$ did not inhibit TEinduced hemolysis. Moreover, the inhibitory extent at the maximal given dose of all cations except $\mathrm{La}^{3+}$ was also diminished. These corrected results from spectrophotometry were further confirmed by direct erythrocyte counting under microscopy. Our results indicate that the cations, except for $\mathrm{La}^{3+}$, can interfere with the absorbance of hemoglobin, which should be corrected when their inhibitory effects on hemolysis by jellyfish venoms are examined. The variation in the inhibitory effects of cations suggests that the hemolysis by jellyfish venom is mainly attributed to the formation of non-selective cation pore complexes over other potential mechanisms, such as phospholipases A2 (PLA2), polypeptides, protease and damage and mortality from jellyfish stings due to hemolytic toxicity. 


\section{1. Introduction}

33 Jellyfish are free-swimming marine animals consisting of a gelatinous umbrella-shaped bell and trailing 34 tentacles. While they are found in coastal water zones worldwide, jellyfish populations fluctuate greatly in accordance with ocean climate and, perhaps, other factors related to human interactions (Williamson et al. 1984; Winter et al. 2010). Jellyfish range from about one millimeter to nearly two meters in bell height and diameter; the tentacles that rim the umbrella typically extend beyond their bell dimension. Contact with jellyfish tentacles, even when beached and dying, can trigger millions of nematocysts to pierce the skin and inject venom through inverted long spiny tubules, thereby causing toxic manifestations from no effect to extreme pain and even death (Carrette \& Seymour 2004).

The jellyfish venom in the nematocyst, similarly to many other types of venom, is a complex mixture of bioactive proteins and peptides that have demonstrated a wide spectrum of biological activities (Bloom et al. 1998; Chung et al. 2001; Yanagihara et al. 2002; Sanchez-Rodriguez et al. 2006; Brinkman \& Burnell 2008), including dermonecrotic, cardiotoxic, neurotoxic, hemolytic, enzymatic, immunogenic and inflammatory effects. Despite over 50 years of research, the pathophysiological processes and mechanisms of the toxic proteins and peptides in this venom have yet to be elucidated. In general, the main cause of death is believed to be cardiotoxicity, while the hemolytic activity is considered a preliminary damage factor and offers an approach to disentangle the complex venom. However, it is reported that hemolysis can range from simple nuisance to serious pathological and lethal events, and is a frequent effect of a number of jellyfish venoms acting as lytic protein/peptides that alter cell permeability resulting in ion transport, cell swelling and osmotic lysis, whereas others are phospholipases inducing degradation of bilayer phospholipids or channel-forming agents embedded into the membrane (Mariottini 2014).

Determining the optical absorbance of released hemoglobin from lysed erythrocytes at $414 \mathrm{~nm}$ or 545 $\mathrm{nm}$ by spectrophotometery is a simple method to test the hemolytic activity of jellyfish venom. This method is widely utilized in cytolytic activity evaluation, hemolytic compound purification and identification, and the identification of inhibitors necessary to explore the hemolytic mechanism and develop novel anti-hemolytic strategies. Dozens of compounds, including osmotic protectants, lipids, proteases, antioxidants and cations, have demonstrated the potential to prevent hemolysis induced by jellyfish venom by either impeding the destruction of membrane lipids or hindering the formation of pores on the cell membrane ( $\mathrm{Li}$ et al. 2005; Marino et al. 2008; Marino et al. 2009; Morabito et al. 2014). Compared with various types of inhibitors, certain cations, such as $\mathrm{La}^{3+}$ (Bailey et al. 2005), $\mathrm{Mn}^{2+}(\mathrm{Li}$ et al. 2005), $\mathrm{Zn}^{2+}$ ( $\mathrm{Yu}$ et al. 2007), $\mathrm{Cu}^{2+}$ (Marino et al. 2009) and $\mathrm{Fe}^{2+}$ (Yu et al. 2007), are usually effective at millimolar concentrations, a relatively high dose that partially precipitates the jellyfish proteins, such as collagen and other toxic compounds. Cations that are colored in aqueous solutions, such as $\mathrm{Cu}^{2+}$ and $\mathrm{Fe}^{2+}$, 
66 may interfere with the absorbance of hemoglobin by spectrophotometry, raising concerns regarding 67 whether this testing method reveals the true inhibitory effects of cations on the hemolytic activity of 68 jellyfish venom. In the current study, we aim to determine the intervention effects of cations $\mathrm{La}^{3+}, \mathrm{Mn}^{2+}$, $69 \mathrm{Zn}^{2+}, \mathrm{Cu}^{2+}$ and $\mathrm{Fe}^{2+}$ on the hemolytic activity of jellyfish venom and to further exploit its possible 70 mechanism underlying the hemolytic activity of jellyfish venom.

71

72 


\section{2. Materials and methods}

\section{2.1. Preparation of tentacle extract from the jellyfish $C$. capillata}

75 Specimens of C. capillata collected in June 2015 in the Sanmen Bay, East China Sea, were identified by 76 Professor Huixin Hong from the Fisheries College of Jimei University, Xiamen, China. The isolated tentacles were placed in plastic bags with dry ice and immediately shipped to Shanghai, where the samples were stored in a $-80{ }^{\circ} \mathrm{C}$ freezer until use. The TE preparation procedure has been described in previous reports ( Wang et al. 2013a; Wang et al. 2013b; Wang et al. 2013c; Wang et al. 2013d; Wang et al. 2014; Zhang et al. 2014). Briefly, tentacles at $-80{ }^{\circ} \mathrm{C}$ were thawed and immersed in seawater (28 g/L $\mathrm{NaCl}, 5 \mathrm{~g} / \mathrm{L} \mathrm{MgCl}{ }_{2} \cdot 6 \mathrm{H}_{2} \mathrm{O}, 0.8 \mathrm{~g} / \mathrm{L} \mathrm{KCl}, 1.033 \mathrm{~g} / \mathrm{L} \mathrm{CaCl}_{2}$ ) to allow tissue autolysis and stirred gently for 4 days. The autolyzed mixture was then centrifuged at $10,000 \times \mathrm{g}$ for $15 \mathrm{~min}$, and the resultant supernatant liquid was collected as the TE. The TE was dialyzed against PBS (pH 7.4, $0.01 \mathrm{M}$ ) for 8 hours before use. All the procedures were performed at $4{ }^{\circ} \mathrm{C}$.

\subsection{Erythrocyte suspension}

Samples of blood were drawn through the tail vein of male Kunming mice (3-6 months) that were purchased from the Laboratory Animal Center of the Second Military Medical University (SMMU). The mice were provided with sufficient food and water, and all animal handlings were approved by the SMMU Ethics Committee. Fresh heparinized mouse blood $(100 \mu \mathrm{L})$ was suspended in $10 \mathrm{~mL} 0.01 \mathrm{M}$ phosphate buffer containing $0.9 \% \mathrm{NaCl}\left(\mathrm{pH}=7.35,300 \mathrm{mOsm} / \mathrm{kgH}_{20}\right)$. To prepare a pure erythrocyte suspension, the diluted blood sample was centrifuged at $1,000 \times g$ for $10 \mathrm{~min}$. The supernatant buffy coat and blood serum were discarded, and the erythrocyte pellet was washed twice and suspended in the same buffer to a final concentration of $0.45 \%$ (v/v) (Kang et al. 2009; Li et al. 2013; Wang et al. 2013d).

\section{2.3. Hemoglobin solution}

95 In total, $10 \mathrm{~mL}$ of erythrocyte suspension were transferred to a $15 \mathrm{~mL}$ centrifugal tube and subjected to a 96 series of sonication periods. After sonication for $60 \mathrm{~s}$ in total, the samples were allowed to cool for $10 \mathrm{~s}$ 97 between ultrasound pulses, using a Misonix S-4000 sonicator (Qsonica, Newtown, CT, USA) set to 20 $98 \mathrm{kHz}$ and $25 \mathrm{~W}$. The sonicated erythrocyte sample was centrifuged at $10,000 \times g$ for 30 min to remove the 99 fragmentized cell membrane and released organelles, and the resultant supernatant was hemoglobin 100 solution.

\section{2.4. Hemolytic test by spectrophotometry}

102 The hemolytic activity of TE was first tested by spectrophotometry. Various concentrations of TE (30, 90, $103180,270,360,450$ and $540 \mu \mathrm{g} / \mathrm{mL})$ were added to the erythrocyte suspension $(100 \mu \mathrm{L}, 0.45 \%$ in $0.01 \mathrm{M}$ 104 phosphate buffer containing $0.9 \% \mathrm{NaCl}, \mathrm{pH}=7.35,300 \mathrm{mOsm} / \mathrm{kgH}_{20}$ ). The total volume of the test 105 system was $200 \mu \mathrm{L}$. The samples were incubated at $37^{\circ} \mathrm{C}$ for $30 \mathrm{~min}$ in a water bath accompanied by 106 mild horizontal shaking. The intact erythrocytes and erythrocyte ghosts were removed by centrifugation at 
$1072,000 \times g$ for $5 \mathrm{~min}$. A $150 \mu \mathrm{L}$ portion of the supernatant fluid was transferred to a 96 -well microplate,

108 and its optical absorbance (OD) was measured at $415 \mathrm{~nm}$ by spectrophotometry. The concentration of the 109 released hemoglobin from the lysed erythrocytes was taken as the index of the TE-induced hemolysis.

110 The negative (0.01 M phosphate buffer) and positive $(30 \mu \mathrm{g} / \mathrm{mL}$ saponin) controls were taken as $0 \%$ and

$111100 \%$ hemolysis, respectively. The hemolytic activity of TE was expressed as \% absorbance, compared to

112 the positive control group.

\section{2.5. Cation interventions}

114 Different amounts of $\mathrm{LaCl}_{3}(1.2,1.4,1.6$ and $1.8 \mathrm{mM}), \mathrm{MnCl}_{2}(20,40,50,100$ and $400 \mathrm{mM}), \mathrm{ZnCl}_{2}(10$, $11520,40$ and $100 \mathrm{mM}), \mathrm{CuCl}_{2}(30,60,90$ and $120 \mu \mathrm{M})$ and $\mathrm{FeSO}_{4}(20,40,80$ and $120 \mathrm{mM})$ dissolved in $1160.01 \mathrm{M}$ phosphate buffer were added to an erythrocyte suspension $(100 \mu \mathrm{L}, 0.45 \%$ in $0.01 \mathrm{M}$ phosphate 117 buffer containing $0.9 \% \mathrm{NaCl}, \mathrm{pH}=7.35,300 \mathrm{mOsm} / \mathrm{kgH}_{20}$ ), followed by the addition of $360 \mu \mathrm{g} / \mathrm{mL} \mathrm{TE}$, to 118 test their inhibitory effect on TE-induced hemolysis. Similarly, the same cation solutions were added to $119100 \mu \mathrm{L}$ of hemoglobin suspension to determine the effect of the cations on the absorbance of hemoglobin 120 at $414 \mathrm{~nm}$. A Nanodrop 1000 (Thermo, America) was used to measure the UV-Vis spectra of hemoglobin 121 solution ranging from 220 to $750 \mathrm{~nm}$ in the presence of $\mathrm{Cu}^{2+}(30,60,120 \mu \mathrm{M})$ and $\mathrm{Fe}^{2+}(20,40,120 \mathrm{mM})$.

\section{2.6. Confocal laser scanning microscopy (CLSM)}

123 Direct erythrocyte counting was also carried out using CLSM. To determine the effect of cations on TE124 induced hemolysis, $\mathrm{LaCl}_{3}(1.8 \mathrm{mM}), \mathrm{MnCl}_{2}(400 \mathrm{mM}), \mathrm{ZnCl}_{2}(100 \mathrm{mM}), \mathrm{CuCl}_{2}(120 \mu \mathrm{M})$ or $\mathrm{FeSO}_{4}(120$ $125 \mathrm{mM}$ ) were added to the erythrocyte solution, followed by $360 \mu \mathrm{g} / \mathrm{mL}$ TE. After incubation at $37^{\circ} \mathrm{C}$ for 30 126 min in a water bath, accompanied by mild horizontal shaking, the erythrocyte suspension was mixed and 127 transferred to a confocal dish for cell counting.

\section{2.7. Data analysis}

129 All the quantitative data are expressed as the mean \pm SD. Statistical analyses were performed using one130 way ANOVA and followed by Student-Newman-Keuls test with the SPSS 22.0 software. The pictures 131 were depicted with the Origin software. A 0.05 level of probability was used as the level of significance.

\section{2.8. Ethical statement}

133 The investigation was carried out in conformity with the requirements of the Ethics Committee of the 134 Second Military Medical University and National Institutes of Health (NIH) guide for care and use of 135 Laboratory animals (NIH Publications No. 8023). Jellyfish catching was permitted by the East China Sea 136 Branch, State Oceanic Administration, People's Republic of China. 


\section{3. Results}

\section{3.1. Dose-dependent TE hemolysis by spectrophotometry}

141 Using current spectrophotometric methods, we examined the dose-dependent relationship of hemolysis by

142 TE from the jellyfish $C$. capillata. Figure 1 shows a dose-response curve depicted by the Hill equation

143 within the TE dose of $540 \mu \mathrm{g} / \mathrm{mL}$. The dissociation equilibrium constant $\left(K_{\mathrm{d}}\right)$ value (Tomasi et al. 2013;

144 Dupin et al. 2015) was $176.2 \pm 8.2 \mu \mathrm{g} / \mathrm{mL}$. The hemolytic curve slowly increased up to $90 \mu \mathrm{g} / \mathrm{mL}$, 145 reaching values of less than $10 \%$, and then sharply increased to $360 \mu \mathrm{g} / \mathrm{mL}$, reaching the value of 146 approximately $90 \%$. When the exposure concentrations were greater than $360 \mu \mathrm{g} / \mathrm{mL}$, the curve began to 147 reach the maximal plateau. Thus, for all future experiments, we uniformly utilized the TE concentration 148 of $360 \mu \mathrm{g} / \mathrm{mL}$ to evaluate TE hemolysis.

\section{3.2. Inhibitory effects of cations on TE-induced hemolysis by spectrophotometry}

150 Several studies (Rosenthal et al. 1990; Edwards \& Hessinger 2000; Bailey et al. 2005) have previously 151 reported that the cations $\mathrm{La}^{3+}, \mathrm{Mn}^{2+}, \mathrm{Cu}^{2+}, \mathrm{Zn}^{2+}$ and $\mathrm{Fe}^{2+}$ antagonize hemolysis induced by nematocyst 152 venom or jellyfish TE by either blocking the venom-formed membrane pore or stabilizing the cell 153 membrane. We, therefore, examined the anti-hemolytic effects of the above cations on TE-induced

154 hemolysis using traditional spectrophotometric methods. As expected, all cations displayed significant 155 dose-dependent anti-hemolytic effects on TE-induced hemolysis, although with differing inhibitory 156 concentrations and $K_{\mathrm{d}}$ values (Figure 2A-E). The effective inhibitory concentrations of the non-specific 157 ion channel blocker $\mathrm{La}^{3+}$ were between $1 \mathrm{mM}$ and $1.8 \mathrm{mM}$, with a $K_{\mathrm{d}}$ value $1.5 \pm 0.01 \mathrm{mM}$. $\mathrm{Cu}^{2+}$ 158 displayed an even stronger suppression of TE-induced hemolysis; its inhibitory concentration was less 159 than $120 \mu \mathrm{M}$, and the $K_{\mathrm{d}}$ value was $71.9 \pm 6.5 \mu \mathrm{M}$. Other bivalent cations, including $\mathrm{Mn}^{2+}, \mathrm{Zn}^{2+}$ and $\mathrm{Fe}^{2+}$, 160 displayed relatively weaker suppressive effects on TE-induced hemolysis compared with $\mathrm{La}^{3+}$ and $\mathrm{Cu}^{2+}$. 161 Their ranges of inhibitory concentrations were $\sim 400 \mathrm{mM}, \sim 120 \mathrm{mM}$ and $\sim 100 \mathrm{mM}$, with $K_{\mathrm{d}}$ values of 93.2 $162 \pm 7.0 \mathrm{mM}, 38.6 \pm 36.3 \mathrm{mM}$ and $32.8 \pm 76.1 \mathrm{mM}$, respectively. Moreover, to show the anti-hemolysis 163 effects of cations more distinctly, we compared the respective maximal suppressive extents of the five 164 cations with TE treatment group (Figure 2F). According to the spectrophotometric values, $\mathrm{La}^{3+}, \mathrm{Cu}^{2+}$, $165 \mathrm{Zn}^{2+}$ and $\mathrm{Fe}^{2+}$ resulted in complete inhibitions of less than $10 \%$, while $\mathrm{Mn}^{2+}$ showed partial suppression 166 with a maximum inhibition of approximately 40\%. Therefore, our results showed that the inhibitory 167 effects of cations on TE-induced hemolysis were in accordance with previous investigations.

\section{3.3. Influences of cations on the hemolytic test system by spectrophotometry}

169 In the process of spectrophotometric hemolysis determination, we observed that some cations resulted in 170 colored aqueous solutions, such as $\mathrm{Cu}^{2+}$ (green), $\mathrm{Fe}^{2+}$ (aqua) and $\mathrm{Mn}^{2+}$ (red); in addition, the $\mathrm{Zn}^{2+}$ solution 171 was slightly ivory as a result of the high concentration-induced hydrolysis. Although erythrocytes and 172 hemoglobin exhibit specific absorbance peaks at $414 \mathrm{~nm}$ and $545 \mathrm{~nm}$, we were interested whether these 
173 colorful cations influenced the test system, thereby complicating an analysis of their effects on TE-

174 induced hemolysis. We first compared the absorbance values of the colored cation solutions at their 175 maximum anti-hemolytic concentrations at $415 \mathrm{~nm}$ (Figure $3 \mathrm{~A}$ ). $\mathrm{La}^{3+}, \mathrm{Mn}^{2+}$ and $\mathrm{Cu}^{2+}$ displayed similar

176 values to that of control, while $\mathrm{Zn}^{2+}$ and $\mathrm{Fe}^{2+}$ showed small increases. We then tested the effects of the 177 cations on the $0.45 \%$ erythrocyte solutions (Figure 3B). As expected, the colorful $\mathrm{Zn}^{2+}, \mathrm{Cu}^{2+}$ and $\mathrm{Fe}^{2+}$ 178 cations resulted in a decrease in the absorbance values of the erythrocytes, while $\mathrm{Mn}^{2+}$ increased the 179 absorbance values and the transparent $\mathrm{La}^{3+}$ had little effect, suggesting that the cation colors might 180 interfere with the absorbance spectrum of hemoglobin.

\section{3.4. Effect of cations on the hemoglobin solution}

182 We tested the effects of cations, at the same concentrations used above, on released hemoglobin from a $1830.45 \%$ erythrocyte suspension (Figure 4). We did not see any effect by the transparent $\mathrm{La}^{3+}$ on the 184 hemoglobin solutions (Figure 4A). The $\mathrm{Mn}^{2+}$ solution displayed a small decrease in the absorbance values 185 (Figure 4B). The colorful $\mathrm{Zn}^{2+}, \mathrm{Cu}^{2+}$ and $\mathrm{Fe}^{2+}$ greatly diminished the absorbance values of hemoglobin at 186 the given concentrations; the resulting $K_{\mathrm{d}}$ values were $35.9 \pm 25.6 \mathrm{mM}, 77.5 \pm 7.7 \mu \mathrm{M}$ and $17.6 \pm 66.4$ $187 \mathrm{mM}$, respectively (Figure $4 \mathrm{C}-\mathrm{E}$ ). $\mathrm{Cu}^{2+}$ is the only one of the five cations that was used in $\mu \mathrm{M} / \mathrm{L}$ and $188 \mathrm{Fe}^{2+}$ has a millimolar concentration in blood, so we measured the UV-Vis spectra of hemoglobin 189 solution in the presence of $\mathrm{Cu}^{2+}(30,60,120 \mu \mathrm{M})$ and $\mathrm{Fe}^{2+}(20,40,120 \mathrm{mM})$ (Figure 5). The results 190 showed that, at $415 \mathrm{~nm}$ where hemoglobin has a peak absorption, $\mathrm{Cu}^{2+}(30,60,120 \mu \mathrm{M})($ Figure $5 \mathrm{~A})$ and $191 \mathrm{Fe}^{2+}(120 \mathrm{mM})$ (Figure 5B) obviously decreased the absorbance value of hemoglobin. These experiments 192 indicate that the colorful cations can change the absorbance values of erythrocytes and hemoglobin at 415 $193 \mathrm{~nm}$, thereby influencing the hemolytic test system.

\section{3.5. Correction of the inhibitory effects of cations on TE-induced hemolysis}

195 Therefore, the hemolytic effects of the colored cations can be separated into two effects. The first is the 196 true inhibition of TE-induced hemolysis, and the other is a false positive effect caused by the modulation 197 of the hemoglobin absorbance by the colored cation solution. Because the absorbance values of 198 hemoglobin were modified in proportion to the cation concentration, and every tested concentration was 199 determined, we used the equation ' $y=a x$ ' to adjust the hemolytic ratio at every given concentration, where 200 ' $y$ ' is the real hemolytic ratio, ' $x$ ' is the determined hemolytic ratio, and ' $a$ ' is an adjustment coefficient 201 that is the inverse of the ratio of cations at the corresponding concentration. Except for the transparent $202 \mathrm{La}^{3+}$ (Figure 6A), the anti-hemolysis curves of four other cations were right-shifted. The corrected $K_{\mathrm{d}}$ 203 values were $1.4 \pm 6.5 \mathrm{mM}, 45.8 \pm 15 \mathrm{mM}, 128.5 \pm 130 \mu \mathrm{M}$ and $53.1 \pm 111.3 \mathrm{mM}$ for $\mathrm{La}^{3+}, \mathrm{Zn}^{2+}, \mathrm{Cu}^{2+}$ and $204 \mathrm{Fe}^{2+}$, respectively (Figure 6). To our surprise, $\mathrm{Mn}^{2+}$ did not show any inhibition after correction (Figure 205 6B). Meanwhile, all cations at the given maximal concentrations displayed much smaller inhibitory 206 effects on TE-induced hemolysis although the differences were still significant. Thus, the correction 
207 indicated that the anti-hemolytic effects of cations $\mathrm{Mn}^{2+}, \mathrm{Cu}^{2+}, \mathrm{Zn}^{2+}$ and $\mathrm{Fe}^{2+}$ (Figure 6B-6E) on TE-

208 induced hemolysis were over-estimated and must be corrected using their respective cation-hemoglobin

209 concentration curves.

\section{3.6. Effects of the cations on TE-induced hemolysis under microscopy}

211 To further confirm our results, we counted the erythrocytes under a microscope after the co-incubation 212 with cations alone or cations in the presence of TE, and compared the erythrocyte numbers before and 213 after TE treatment to give the "Erythrocyte amount (\%)" (Figure 7). The number of erythrocytes was 214 significantly decreased in the TE group, and their shape was changed from the typical biconcave discoid 215 to convex and rounded. In all cation groups, the internal cations did not change the number or the shapes 216 of the erythrocytes. To our surprise, a large amount of floccule was observed encircling the erythrocytes, 217 especially in the $\mathrm{La}^{3+}, \mathrm{Zn}^{2+}, \mathrm{Fe}^{2+}$ and $\mathrm{Cu}^{2+}$ groups, which might be due to the interaction of cations with 218 the collagen in jellyfish TE. In the $\mathrm{La}^{3+}, \mathrm{Zn}^{2+}, \mathrm{Fe}^{2+}$ and $\mathrm{Cu}^{2+}$ groups, more erythrocytes were present than 219 in the TE-alone positive control group. No change in the erythrocyte amount was observed in the $\mathrm{La}^{3+}$ 220 group, suggesting the obvious inhibitory effect of $\mathrm{La}^{3+}$ on TE-induced hemolysis. $\mathrm{Cu}^{2+}, \mathrm{Zn}^{2+}$ and $\mathrm{Fe}^{2+}$ also 221 displayed strong anti-hemolytic effects, while the erythrocyte count in the $\mathrm{Mn}^{2+}$ group was the lowest, 222 indicating the weakest, or absence of, anti-hemolytic effects. These results indicate that the inhibitory 223 effects of the cations on TE-induced hemolysis, as examined under microscopy, were roughly consistent 224 with the determination by spectrophotometry after correction. 


\section{4. Discussion}

227 We have examined the anti-hemolytic effects of five cations with reported inhibitory effects on the TE228 induced hemolysis from the jellyfish $C$. capillata. All the cations, except the transparent $\mathrm{La}^{3+}$, were found 229 to significantly influence the erythrocyte test system and the hemoglobin system by virtue of their colored 230 aqueous solutions. The true antagonistic effects of the cations on TE-induced hemolysis were actually 231 weaker than those tested by in previous spectrophotometry studies. For this study, corrected inhibitions 232 were calculated from the effect of colored solutions on hemoglobin absorbance under the same conditions; 233 these corrected values were supported by direct counting of erythrocytes under microscopy.

\section{4.1. Hemolytic determination and intervention}

235 Hemolysis is a frequent effect of jellyfish stings. This dangerous condition is known to be caused by the 236 jellyfish venom and can be lethal. Mature mammalian erythrocytes are highly differentiated cells that 237 possess a large amount of hemoglobin without intracellular organelles, such as mitochondria and a 238 nucleus; thus, the concentration of released hemoglobin at $414 \mathrm{~nm}$ (Chung et al. 2001; Garcia-Arredondo 239 et al. 2014; Kang et al. 2014; Morabito et al. 2014) or $545 \mathrm{~nm}$ (Kang et al. 2009) is normally proportional 240 to the number of lysed erythrocytes and reflects the hemolytic activity. This simple method for 241 determination of hemolysis is widely used to compare hemolytic potencies, explore molecular 242 mechanisms and search for potential interventions (Long \& Burnett 1989). Concentrations inducing 50\% 243 hemolysis by jellyfish venoms vary from ' $\sim \mathrm{ng} / \mathrm{mL}$ ' to ' $\sim \mathrm{mg} / \mathrm{mL}$ ' depending on the jellyfish species and 244 sample extraction methods (Mariottini 2014). The hemolytic activity of crude venom from isolated 245 nematocysts of the Hawaiian box jellyfish Carybdea alata was $1 \sim 10 \mu \mathrm{g} / \mathrm{mL}$ and was reduced after 246 exposure to proteolytic enzymes (trypsin, collagenase and papain), carbohydrates (D-lactulose and D247 galactose, among others), EDTA and cations $\left(\mathrm{K}^{+}\right.$and $\left.\mathrm{Mn}^{2+}\right)$ but was increased by other cations, including $248 \mathrm{Mg}^{2+}, \mathrm{Ca}^{2+}$ and $\mathrm{Zn}^{2+}$ (Chung et al. 2001). In another study, the hemolytic activity of the full venom of 249 Rhopilema esculentum Kishinouye was $3.4 \mu \mathrm{g} / \mathrm{mL}$ and was affected by $\mathrm{pH}$, temperature, EDTA, $250\left(\mathrm{NH}_{4}\right)_{2} \mathrm{SO}_{4}$ and all tested divalent cations $\left(\mathrm{Mg}^{2+}, \mathrm{Cu}^{2+}, \mathrm{Zn}^{2+}, \mathrm{Fe}^{2+}, \mathrm{Ca}^{2+}\right.$ and $\left.\mathrm{Mn}^{2+}\right)(\mathrm{Yu}$ et al. 2007). 251 Hemolysis by the crude venom of Aiptasia mutabilis was prevented by $\mathrm{Ca}^{2+}, \mathrm{Ba}^{2+}$ and $\mathrm{Cu}^{2+}$, and 252 suppressed to a minor extent by $\mathrm{Mg}^{2+}$ and $\mathrm{K}^{+}$(Marino et al. 2009). In our previous study (Lu et al. 2012), 253 the hemolytic activity of TE from the jellyfish $C$. capillata was inhibited by $\mathrm{Mn}^{2+}, \mathrm{Zn}^{2+}, \mathrm{La}^{3+}, \mathrm{Cu}^{2+}$ and $254 \mathrm{Fe}^{2+}$, while the hemolytic activity was increased in the presence of $\mathrm{K}^{+}, \mathrm{Ca}^{2+}, \mathrm{Mg}^{2+}$ and $\mathrm{NH}_{4}^{+}$.

255 Except for $\mathrm{K}^{+}, \mathrm{Ca}^{2+}$ and $\mathrm{Mg}^{2+}$, it appears that other tested cations, including $\mathrm{Mn}^{2+}, \mathrm{Zn}^{2+}, \mathrm{La}^{3+}, \mathrm{Cu}^{2+}$ and $256 \mathrm{Fe}^{2+}$, have an antagonistic effect on hemolysis by jellyfish venoms ( $\mathrm{Lu}$ et al. 2012). Because traditional 257 spectrophotometric methods test the absorbance of hemoglobin, which indirectly reflects the extent of 258 erythrocyte hemolysis, cations interacting with hemoglobin or interfering with the absorbance of 
259

260

261

262

263

264

265

266

267

268

269

270

271

272

273

274

275

276

277

278

279

280

281

282

283

284

285

286

287

288

289

290

291

292

hemoglobin will lead to a false positive. Though the antagonist effects have been demonstrated to be reproducible, the colors of some cations, such as $\mathrm{Cu}^{2+}$ and $\mathrm{Fe}^{2+}$, should lead researchers to be more cautious in judging their effects. Our initial results suggested that all tested cations, except for the transparent $\mathrm{La}^{3+}$, significantly shifted the absorbance curves of hemoglobin to the right. Accordingly, the corrected antagonistic effects were right-shifted, except in the cases of $\mathrm{La}^{3+}$ and $\mathrm{Mn}^{2+}$. $\mathrm{La}^{3+}$ displayed no effect on the curve, and $\mathrm{Mn}^{2+}$ showed no antagonistic effect after correction, which came as a surprise to us. Notwithstanding the $K_{\mathrm{d}}$ values, the maximum inhibitory values were also decreased in $\mathrm{Zn}^{2+}, \mathrm{Cu}^{2+}$ and $\mathrm{Fe}^{2+}$. These results were further supported by the direct counting of erythrocytes using confocal microscopy.

\subsection{Hemolytic mechanism and compounds}

Ever since hemolytic proteins were first purified and identified as CrTX-A and CrTX-B from the venom of the jellyfish Carybdea rastoni (Nagai et al. 2000), jellyfish hemolytic proteins have been developed as a novel family of taxonomically restricted cnidarian toxins $(42-46 \mathrm{kDa})$ in the jellyfish species Chironex fleckeri, Cyanea nozakii Kishinouye, Chironex yamaguchii (as Chiropsalmus quadrigatus), and Alatina moseri (as Carybdea alata) (Chung et al. 2001; Nagai et al. 2002; Brinkman et al. 2014; Mariottini 2014; Strobos 2014). These hemolytic proteins were identified as pore-forming toxins by bioinformatics, leading to the hemolytic activity of jellyfish venom. In addition to the non-selective formation of pore complexes, at least the following four other factors have been shown to cause the hemolytic effects of jellyfish venom: (1) Protease and collagenase that are able to break the cell membrane via digestion of membrane proteins ( $\mathrm{Li}$ et al. 2014; $\mathrm{Li}$ et al. 2016). (2) Phospholipase $\mathrm{A}_{2}\left(\mathrm{PLA}_{2}\right)$, the activity of which, in jellyfish venom, was discovered long ago. Several phospholipases have been identified recently using transcriptomic and proteomic analyses (Nevalainen et al. 2004; Weston et al. 2013; Heo et al. 2016). (3) Polypeptides: two novel cytolysins, designated oshem1 and oshem2, with respective molecular weights of 3.0 and $3.4 \mathrm{kDa}$, were identified from the tentacle of the Hydrozoan Olindias sambaquiensis (Junior et al. 2014). (4) Oxidizing compounds: we have previously reported that lipid peroxidation is a potential mechanism besides pore formation underlying hemolysis by TE from the jellyfish $C$. capillata (Ayed et al. 2011; Wang et al. 2013d). Therefore, the hemolytic activity of jellyfish venom is a combined effect by hemolysins, proteases, phospholipases, polypeptides and oxidizing materials. The major factors leading to hemolysis vary greatly between jellyfish species. Interestingly, functional assays of two pairs of structurally similar hemolytic proteins from $C$. feckeri, CfTX-1/2 and CfTX-A/B, demonstrated that CfTX-1/2 causes profound effects on the cardiovascular system of anesthetized rats, whereas CfTX-A/B elicits only minor cardiovascular effects but possesses a hemolytic activity at least 30 times greater than that of CfTX-1/2, indicating that the hemolytic proteins of jellyfish venoms have diversified structurally and functionally during evolution (Brinkman et al. 2014). 
293

294

295

296

297

298

299

300

301

302

303

304

305

306

307

308

309

310

311

312

313

314

315

316

317

318

319

320

321

322

323

324

325

Our results showed that the antagonistic curves of the cations significantly right-shifted, except for $\mathrm{La}^{3+}$, with respect to the hemolytic activity of jellyfish venom. The following four factors may also contribute to the partial inhibition of TE hemolytic activity (except in the case of $\mathrm{Mn}^{2+}$ ): (1) Direct inhibition of the non-selective cation channel. $\mathrm{La}^{3+}$ is a well-known non-selective cation channel blocker that also functions as the best antagonist of the hemolytic activity of jellyfish venom (Rosenthal et al. 1990; Bailey et al. 2005). The potent anti-hemolytic activity of $\mathrm{La}^{3+}$ suggests that pore formation is a major mechanism of hemolysis by jellyfish venoms (Wang et al. 2013d; Ponce et al. 2016). (2) Competition between the active cations and those essential for hemolytic activity. It was reported that the hemolytic activity of crude venom from $C$. alata was dependent on the presence of divalent cations, and $\mathrm{Ca}^{2+}$ or $\mathrm{Mg}^{2+}$ was necessary for hemolytic activity, which might be essential for the activity of venom proteases, collagenases and $\mathrm{PLA}_{2}$ (Chung et al. 2001; Helmholz et al. 2007). (3) Stabilization of the cell membrane. It has been reported that $\mathrm{Zn}^{2+}$ and $\mathrm{Cu}^{2+}$ influence membrane fluidity and stability (Razin 1972; RiceEvans 1994) and increase resistance to hemolysis (Lu et al. 2012). The antioxidant effects of cations such as $\mathrm{Fe}^{2+}$ might also hinder pore-formation via oxidation. The variability in the anti-hemolytic effects of cations suggests that the non-selective pore blocked by $\mathrm{La}^{3+}$ contributes the most to the hemolysis of jellyfish venoms, which could be favored by other active components such as proteases, PLA 2 and oxidative materials.

\subsection{In vivo hemolysis and pathophysiological effect}

In vivo hemolysis can occur following a jellyfish sting. Via intravenous administration of TE from jellyfish C. capillata, we showed that in vivo hemolysis consists of the following two phases: a rapid and severe hemolysis in the first $10 \mathrm{~min}$, followed by a gradual hemolysis over $3 \mathrm{~h}$. Correspondingly, the indirect indexes of $\mathrm{K}^{+}$and lactic acid increased, reaching their maximum within $10 \mathrm{~min}$, then recovering to levels higher than normal because of the in vivo compensation mechanism. Although the increase in hemolytic activity occurs quickly, the extent of in vivo hemolysis seemed to be much smaller than that in vitro. We have previously confirmed that the hemolytic activity of TE in diluted blood was much weaker than that in an erythrocyte suspension with the same erythrocyte ration. Both blood serum and albumin dose-dependently inhibited the hemolysis of TE (Xiao et al. 2010; Wang et al. 2012).

Despite the significant prevention from blood serum and albumin, the hemolytic activity of jellyfish is still able to damage the internal organs in direct and indirect ways. As is well known, hemolytic activity usually stems from breaks in the cell membrane and non-specific cytotoxicity, since mature mammalian erythrocytes do not have organelles. Although we do not exclude the existence of components that specifically damage important tissues and organs, the known non-specific cytotoxicity results in a basal toxicity level that can cause direct injuries to all effected organs, including the heart, liver, kidneys and 
326 lungs. The hemolytic proteins CfTX-1 and 2 (Brinkman \& Burnell 2007), isolated from C. fleckeri venom, 327 possess sequence and structural similarity to the two hemolytic proteins CfTX-A and B (Brinkman et al. 328 2014; Jouiaei et al. 2015), also from C. fleckeri venom, which cause profound effects on the

332 cardiovascular system but much smaller effects on erythrocytes. The relationship between these hemolytic proteins indicates the evolutional functional diversification of jellyfish hemolytic proteins with high cardiovascular specificity. We have confirmed that the in vivo hemolysis is not strong enough to cause hypoxia in blood. The hypoxia in tissue and organs mainly stems from insufficient blood perfusion due to heart failure and vascular contraction caused by jellyfish venom.

The indirect damage of hemolysis mainly comes from released products from erythrocytes and cells. The release of large amounts of lactic acid from the erythrocytes significantly lowers the blood $\mathrm{pH}$, leading to severe metabolic acidosis, which can further cause clinical manifestations such as cardiac arrhythmia, respiratory disorders and gastrointestinal symptoms. Another important factor is the elevation of blood potassium from intra-erythrocyte $\mathrm{K}^{+}$release, $\mathrm{H}^{+}-\mathrm{K}^{+}$exchange and intracellular $\mathrm{K}^{+}$release. It has been reported that hyperkalemia is one of the main causes of cardiovascular collapse and mortality by $C$. fleckeri venom; this effect can be improved by zinc gluconate (Yanagihara \& Shohet 2012). The complete inhibition of hemolysis by the non-specific channel blocker $\mathrm{La}^{3+}$, in addition to the partial inhibition by other cations following different mechanisms, supports the hypothesis that the lethal hemolytic mechanism is due to pore formation in cell membrane, favored over other mechanisms, and suggests an important strategy to antagonize hemolysis via pore blockage by cations, channel blockers and other antagonists.

In conclusion, we have repeated and corrected the inhibitory effects of five cations on hemolysis induced by jellyfish venom using spectrophotometric methods, and the results were further confirmed by direct erythrocyte counting under microscopy. With the exception of the transparent non-selective cation channel inhibitor $\mathrm{La}^{3+}$, which displayed complete inhibition, the inhibitory effects of $\mathrm{Cu}^{2+}, \mathrm{Zn}^{2+}$ and $\mathrm{Fe}^{2+}$ were right-shifted and actually weaker than those reported previously. $\mathrm{Mn}^{2+}$ did not have any significant antagonistic effects after the correction was applied. Our results indicate that the cations, except in the case of $\mathrm{La}^{3+}$, interfere with the absorbance of hemoglobin, which should be corrected when their inhibitory effects on the hemolytic activity of jellyfish venoms are tested. The variability in the inhibitory effects by cations supports the hypothesis that hemolysis by jellyfish venom can be attributed to the formation of non-selective cation pore complexes over other potential mechanisms, such as PLA 2 (Helmholz et al. 2007), polypeptides, proteases and oxidation. Blocking the formation of pore complexes may be a useful strategy to improve in vivo damage and mortality of jellyfish stings caused by hemolytic toxicity. 
360

361

362

363

364

365

366

367

368

369

370

371

372

373

374

375

376

377

378

379

380

381

382

383

384

385

386

387

388

389

390

391

392

393

394

395

396

397

398

\section{References}

Ayed Y, Boussabbeh M, Zakhama W, Bouaziz C, Abid S, and Bacha H. 2011. Induction of cytotoxicity of Pelagia noctiluca venom causes reactive oxygen species generation, lipid peroxydation induction and DNA damage in human colon cancer cells. Lipids Health Dis 10:232.

Bailey PM, Bakker AJ, Seymour JE, and Wilce JA. 2005. A functional comparison of the venom of three Australian jellyfish-Chironex fleckeri, Chiropsalmus sp., and Carybdea xaymacana-on cytosolic $\mathrm{Ca}^{2+}$, haemolysis and Artemia sp. lethality. Toxicon 45:233242.

Bloom DA, Burnett JW, and Alderslade P. 1998. Partial purification of box jellyfish (Chironex fleckeri) nematocyst venom isolated at the beachside. Toxicon 36:1075-1085.

Brinkman D, and Burnell J. 2007. Identification, cloning and sequencing of two major venom proteins from the box jellyfish, Chironex fleckeri. Toxicon 50:850-860.

Brinkman D, and Burnell J. 2008. Partial purification of cytolytic venom proteins from the box jellyfish, Chironex fleckeri. Toxicon 51:853-863.

Brinkman DL, Konstantakopoulos N, McInerney BV, Mulvenna J, Seymour JE, Isbister GK, and Hodgson WC. 2014. Chironex fleckeri (box jellyfish) venom proteins: expansion of a cnidarian toxin family that elicits variable cytolytic and cardiovascular effects. $J$ Biol Chem 289:4798-4812.

Carrette T, and Seymour J. 2004. A rapid and repeatable method for venom extraction from Cubozoan nematocysts. Toxicon 44:135-139.

Chung JJ, Ratnapala LA, Cooke IM, and Yanagihara AA. 2001. Partial purification and characterization of a hemolysin (CAH1) from Hawaiian box jellyfish (Carybdea alata) venom. Toxicon 39:981-990.

Dupin L, Zuttion F, Gehin T, Meyer A, Phaner-Goutorbe M, Vasseur JJ, Souteyrand E, Morvan F, and Chevolot Y. 2015. Effects of the surface densities of glycoclusters on the determination of their $\mathrm{IC}_{50}$ and $K_{\mathrm{d}}$ value determination by using a microarray. ChemBioChem 16:2329-2336.

Edwards L, and Hessinger DA. 2000. Portuguese Man-of-war (Physalia physalis) venom induces calcium influx into cells by permeabilizing plasma membranes. Toxicon 38:1015-1028.

Garcia-Arredondo A, Murillo-Esquivel LJ, Rojas A, and Sanchez-Rodriguez J. 2014. Characteristics of hemolytic activity induced by the aqueous extract of the Mexican fire coral Millepora complanata. J Venom Anim Toxins Incl Trop Dis 20:49.

Helmholz H, Ruhnau C, Schutt C, and Prange A. 2007. Comparative study on the cell toxicity and enzymatic activity of two northern scyphozoan species Cyanea capillata (L.) and Cyanea lamarckii (Peron \& Leslieur). Toxicon 50:53-64.

Heo Y, Kwon YC, Shin K, Yoon WD, Han CH, Yum S, and Kim E. 2016. cDNA and gene structures of two phospholipase A2 isoforms, acidic PLA2 PA4 and PLA2 PA3A/PA3B/PA5, in Nemopilema nomurai jellyfish venom. Toxicon 122:160-166. 
399

400

401

402

403

404

405

406

407

408

409

410

411

412

413

414

415

416

417

418

419

420

421

422

423

424

425

426

427

428

429

430

431

432

433

434

435

436

437

Jouiaei M, Casewell NR, Yanagihara AA, Nouwens A, Cribb BW, Whitehead D, Jackson TN, Ali SA, Wagstaff SC, Koludarov I, Alewood P, Hansen J, and Fry BG. 2015. Firing the sting: chemically induced discharge of cnidae reveals novel proteins and peptides from box jellyfish (Chironex fleckeri) venom. Toxins (Basel) 7:936-950.

Junior VH, Zara F, Marangoni S, Toyama Dde O, de Souza AJ, de Oliveira SC, and Toyama MH. 2014. Identification of two novel cytolysins from the hydrozoan Olindias sambaquiensis (Cnidaria). J Venom Anim Toxins Incl Trop Dis 20:10.

Kang C, Han DY, Park KI, Pyo MJ, Heo Y, Lee H, Kim GS, and Kim E. 2014. Characterization and neutralization of Nemopilema nomurai (Scyphozoa: Rhizostomeae) jellyfish venom using polyclonal antibody. Toxicon 86:116-125.

Kang C, Munawir A, Cha M, Sohn ET, Lee H, Kim JS, Yoon WD, Lim D, and Kim E. 2009. Cytotoxicity and hemolytic activity of jellyfish Nemopilema nomurai (Scyphozoa: Rhizostomeae) venom. Comp Biochem Physiol C Toxicol Pharmacol 150:85-90.

Li C, Yu H, Liu S, Xing R, Guo Z, and Li P. 2005. Factors affecting the protease activity of venom from jellyfish Rhopilema esculentum Kishinouye. Bioorg Med Chem Lett 15:5370-5374.

Li R, Yu H, Xing R, Liu S, Qing Y, Li K, Li B, Meng X, Cui J, and Li P. 2013. Isolation and in vitro partial characterization of hemolytic proteins from the nematocyst venom of the jellyfish Stomolophus meleagris. Toxicol In Vitro 27:1620-1625.

Li R, Yu H, Xue W, Yue Y, Liu S, Xing R, and Li P. 2014. Jellyfish venomics and venom gland transcriptomics analysis of Stomolophus meleagris to reveal the toxins associated with sting. J Proteomics 106:17-29.

Li R, Yu H, Yue Y, Liu S, Xing R, Chen X, and Li P. 2016. Combined proteomics and transcriptomics identifies sting-related toxins of jellyfish Cyanea nozakii. J Proteomics 148:57-64.

Long KO, and Burnett JW. 1989. Isolation, characterization, and comparison of hemolytic peptides in nematocyst venoms of two species of jellyfish ( Chrysaora quinquecirrha and Cyanea capillata ). Comp Biochem Physiol B Comp Biochem 94:641-646.

Lu J, Wang QQ, Zhang W, Wang BL, Wang T, Zhang L, Wen XJ, Liu GY, Zhao J, Xiao L, and Zhang LM. 2012. Effect of various cations on hemolytic activity of tentacle-only extract from jellyfish Cyanea capillata. Acad J Sec Mil Med Uinv 33(3): 240-246.

Marino A, Morabito R, and La Spada G. 2009. Factors altering the haemolytic power of crude venom from Aiptasia mutabilis (Anthozoa) nematocysts. Comp Biochem Physiol A Mol Integr Physiol 152:418-422.

Marino A, Morabito R, Pizzata T, and La Spada G. 2008. Effect of various factors on Pelagia noctiluca (Cnidaria, Scyphozoa) crude venom-induced haemolysis. Comp Biochem Physiol A Mol Integr Physiol 151:144-149.

Mariottini GL. 2014. Hemolytic venoms from marine cnidarian jellyfish - an overview. $J$ Venom Res 5:22-32. 
438 Morabito R, Dossena S, La Spada G, and Marino A. 2014. Heavy metals affect nematocysts

439

440

441

442

443

444

445

446

447

448

449

450

451

452

453

454

455

456

457

458

459

460

461

462

463

464

465

466

467

468

469

470

471

472

473

474

475

476 discharge response and biological activity of crude venom in the jellyfish Pelagia noctiluca (Cnidaria, Scyphozoa). Cell Physiol Biochem 34:244-254.

Nagai H, Takuwa K, Nakao M, Ito E, Miyake M, Noda M, and Nakajima T. 2000. Novel proteinaceous toxins from the box jellyfish (sea wasp) Carybdea rastoni. Biochem Biophys Res Commun 275:582-588.

Nagai H, Takuwa-Kuroda K, Nakao M, Oshiro N, Iwanaga S, and Nakajima T. 2002. A novel protein toxin from the deadly box jellyfish (Sea Wasp, Habu-kurage) Chiropsalmus quadrigatus. Biosci Biotechnol Biochem 66:97-102.

Nevalainen TJ, Peuravuori HJ, Quinn RJ, Llewellyn LE, Benzie JA, Fenner PJ, and Winkel KD. 2004. Phospholipase A2 in cnidaria. Comp Biochem Physiol B Biochem Mol Biol 139:731-735.

Ponce D, Brinkman DL, Potriquet J, and Mulvenna J. 2016. Tentacle transcriptome and venom proteome of the Pacific sea nettle, Chrysaora fuscescens (Cnidaria: Scyphozoa). Toxins (Basel) 8:102.

Razin S. 1972. Reconstitution of biological membranes. Biochimica et Biophysica Acta (BBA) Reviews on Biomembranes 265:241-296.

Rice-Evans CA. 1994. Chapter 5 Formation of free radicals and mechanisms of action in normal biochemical processes and pathological states. New Comprehensive Biochemistry 28:131153.

Rosenthal L, Zacchetti D, Madeddu L, and Meldolesi J. 1990. Mode of action of alpha-latrotoxin: role of divalent cations in $\mathrm{Ca}^{2+}$-dependent and $\mathrm{Ca}^{2+}$-independent effects mediated by the toxin. Mol Pharmacol 38:917-923.

Sanchez-Rodriguez J, Torrens E, and Segura-Puertas L. 2006. Partial purification and characterization of a novel neurotoxin and three cytolysins from box jellyfish (Carybdea marsupialis) nematocyst venom. Arch Toxicol 80:163-168.

Strobos J. 2014. An aberrant decision by the European authorities to keep iron dextran on the market. Prescrire International 23:185.

Tomasi G, Nabulsi N, Zheng MQ, Weinzimmer D, Ropchan J, Blumberg L, Brown-Proctor C, Ding YS, Carson RE, and Huang Y. 2013. Determination of in vivo $B_{\max }$ and $K_{\mathrm{d}}$ for $\left[{ }^{11} \mathrm{C}\right]-\mathrm{GR} 103545$, an agonist PET tracer for kappa opioid receptors: A study in nonhuman primates. J Nucl Med 54(4): 600-608.

Wang B, Zhang B, Huo H, Wang T, Wang Q, Wu Y, Xiao L, Ren Y, and Zhang L. 2014. Detection of microvasculature alterations by synchrotron radiation in murine with delayed jellyfish envenomation syndrome. Toxicon 81:48-53.

Wang B, Zhang B, Wang Q, Zhang Z, Nie F, Liu G, Zheng J, Xiao L, and Zhang L. 2013a. Pharmacological studies of tentacle extract from the jellyfish Cyanea capillata in isolated rat aorta. Mar Drugs 11:3335-3349.

Wang B, Zhang L, Zheng J, Wang Q, Wang T, Lu J, Wen X, Zhang B, Liu G, Zhang W, Xiao L, 
477

478

479

480

481

482

483

484

485

486

487

488

489

490

491

492

493

494

495

496

497

498

499

500

501

502

503

504

505

506

507

508

509

510

511

512

513

514

515 and Zhang L. 2013b. Multiple organ dysfunction: a delayed envenomation syndrome caused by tentacle extract from the jellyfish Cyanea capillata. Toxicon 61:54-61.

Wang Q, Xiao L, He Q, Liu S, Zhang J, Li Y, Zhang Z, Nie F, Guo Y, and Zhang L. 2012. Comparison of haemolytic activity of tentacle-only extract from jellyfish Cyanea capillata in diluted whole blood and erythrocyte suspension: diluted whole blood is a valid test system for haemolysis study. Exp Toxicol Pathol 64:831-835.

Wang T, He Q, Xiao L, Wang Q, Zhang B, Wang B, Liu G, Zheng J, Yu B, and Zhang L. 2013c. Mitochondrial dysfunction contributes to the cytotoxicity induced by tentacle extract from the jellyfish Cyanea capillata in rat renal tubular epithelial NRK-52E cells. Toxicon $74: 1-7$.

Wang T, Wen XJ, Mei XB, Wang QQ, He Q, Zheng JM, Zhao J, Xiao L, and Zhang LM. 2013 d. Lipid peroxidation is another potential mechanism besides pore-formation underlying hemolysis of tentacle extract from the jellyfish Cyanea capillata. Mar Drugs 11:67-80.

Weston AJ, Chung R, Dunlap WC, Morandini AC, Marques AC, Moura-da-Silva AM, Ward M, Padilla G, da Silva LF, Andreakis N, and Long PF. 2013. Proteomic characterisation of toxins isolated from nematocysts of the South Atlantic jellyfish Olindias sambaquiensis. Toxicon 71:11-17.

Williamson JA, Le Ray LE, Wohlfahrt M, and Fenner PJ. 1984. Acute management of serious envenomation by box-jellyfish (Chironex fleckeri). Med J Aust 141:851-853.

Winter K, Isbister G, McGowan S, Konstantakopoulos N, Seymour J, and Hodgson W. 2010. A pharmacological and biochemical examination of the geographical variation of Chironex fleckeri venom. Toxicol Lett 192:419-424.

Xiao L, Zhang J, Wang QQ, He Q, Liu SH, Li Y, and Zhang LM. 2010. In vitro and in vivo haemolytic studies of tentacle-only extract from jellyfish Cyanea capillata. Toxicol In Vitro 24:1203-1207.

Yanagihara AA, Kuroiwa JM, Oliver LM, Chung JJ, and Kunkel DD. 2002. Ultrastructure of a novel eurytele nematocyst of Carybdea alata Reynaud (Cubozoa, Cnidaria). Cell Tissue Res 308:307-318.

Yanagihara AA, and Shohet RV. 2012. Cubozoan venom-induced cardiovascular collapse is caused by hyperkalemia and prevented by zinc gluconate in mice. PLoS One 7:e51368.

Yu H, Li C, Li R, Xing R, Liu S, and Li P. 2007. Factors influencing hemolytic activity of venom from the jellyfish Rhopilema esculentum Kishinouye. Food Chem Toxicol 45:1173-1178.

Zhang L, He Q, Wang Q, Zhang B, Wang B, Xu F, Wang T, Xiao L, and Zhang L. 2014. Intracellular $\mathrm{Ca}^{2+}$ overload induced by extracellular $\mathrm{Ca}^{2+}$ entry plays an important role in acute heart dysfunction by tentacle extract from the jellyfish Cyanea capillata. Cardiovasc Toxicol 14:260-274. 
516 Figure Legends

517 Fig. 1. Hemolysis ratio (\%) after $30 \mathrm{~min}$ of treatment with varying TE concentrations. The dose-response 518 curve is depicted based on Hill's co-operation analysis. All data are presented as the mean $\pm \operatorname{SD}(n=3)$.

519

520

521

522

523

524

525

526

A

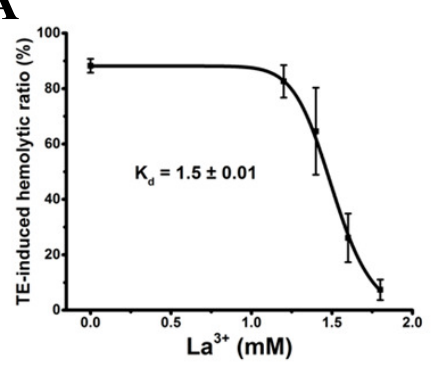

D

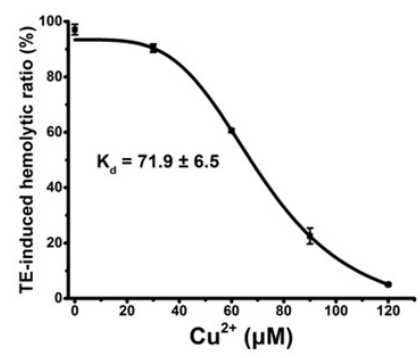

B

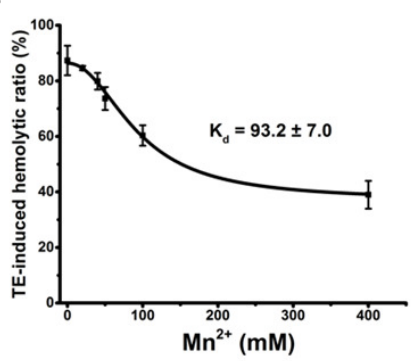

E

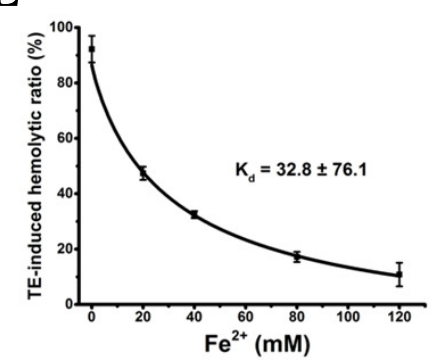

C

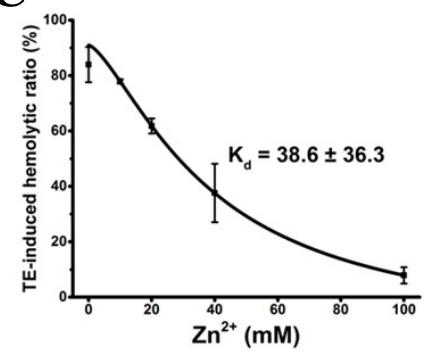

F

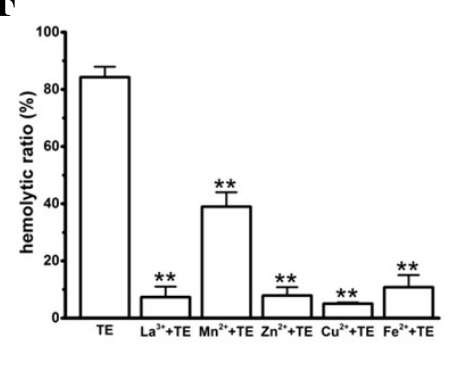


529 Fig. 3. Effects of the cations on an erythrocyte reaction system by spectrophotometry, where the maximal 530 anti-hemolytic concentrations of the cations were used. (A) Optical absorbance (OD) of cations at $415 \mathrm{~nm}$. 531 Control $(0.9 \% \mathrm{NaCl}), \mathrm{La}^{3+}(1.8 \mathrm{mM}), \mathrm{Mn}^{2+}(400 \mathrm{mM}), \mathrm{Zn}^{2+}(100 \mathrm{mM}), \mathrm{Cu}^{2+}(120 \mu \mathrm{M}), \mathrm{Fe}^{2+}(120 \mathrm{mM})$. 532 (B) Optical absorbance (OD) of the erythrocyte reaction system at $415 \mathrm{~nm}$ upon treatment with cations. 533 Control $(0.9 \% \mathrm{NaCl}) ; \mathrm{La}^{3+}(1.8 \mathrm{mM}) ; \mathrm{Mn}^{2+}(400 \mathrm{mM}) ; \mathrm{Zn}^{2+}(100 \mathrm{mM}) ; \mathrm{Cu}^{2+}(120 \mu \mathrm{M}) ; \mathrm{Fe}^{2+}(120 \mathrm{mM})$. 534 All data are demonstrated as the mean $\pm \mathrm{SD}(\mathrm{n}=3)$. $* P<0.05$, compared to the control group.

535

536

537

538 539
A

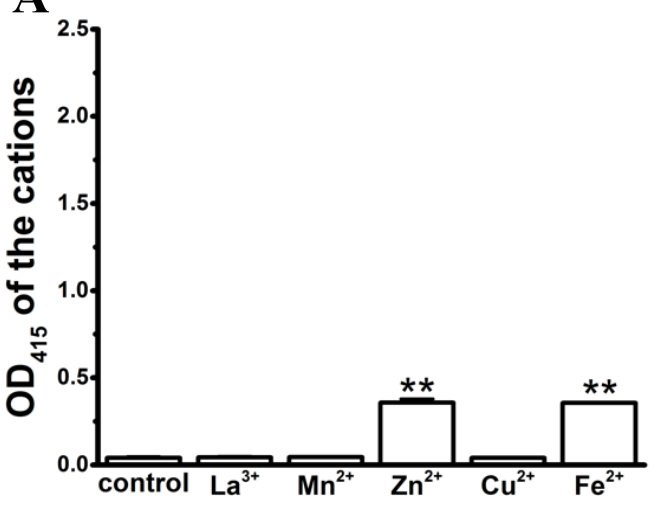

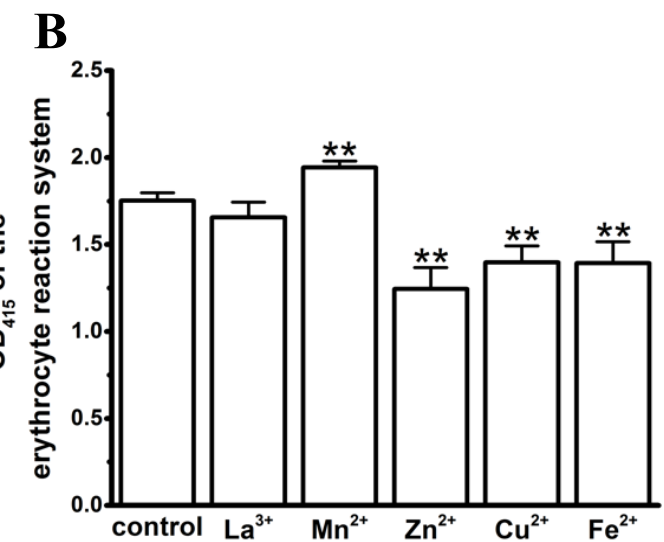

Fig. 4. Effects of the cations on a hemoglobin solution by spectrophotometry. The hemoglobin solution was obtained by sonicating a $0.45 \%$ erythrocyte suspension. $\mathrm{La}^{3+}(\mathrm{A}) ; \mathrm{Mn}^{2+}(\mathrm{B}) ; \mathrm{Zn}^{2+}(\mathrm{C}) ; \mathrm{Cu}^{2+}(\mathrm{D}) ;$ and $\mathrm{Fe}^{2+}(\mathrm{E})$ are displayed. Corresponding dose-response curves are depicted based on Hill's co-operation analysis. All data are demonstrated as the mean $\pm \mathrm{SD}(\mathrm{n}=3)$.

A

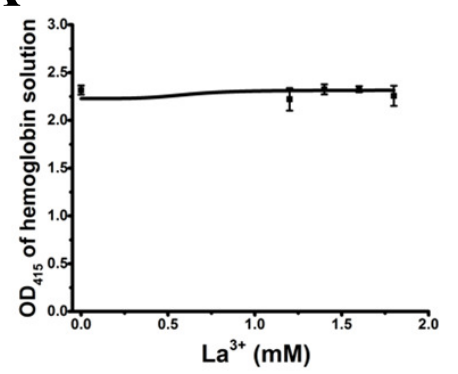

D

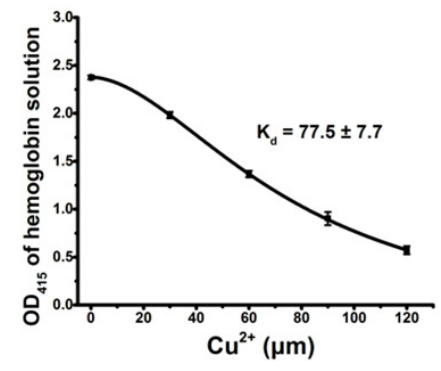

B

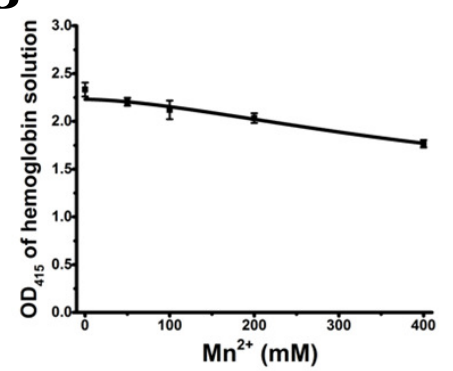

E

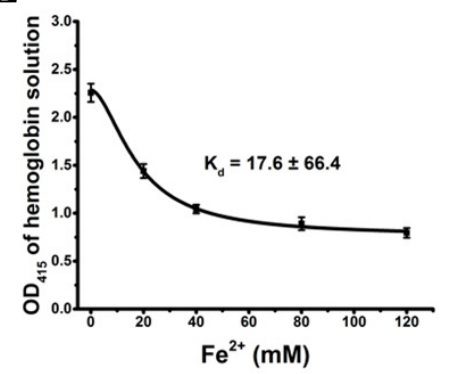

C

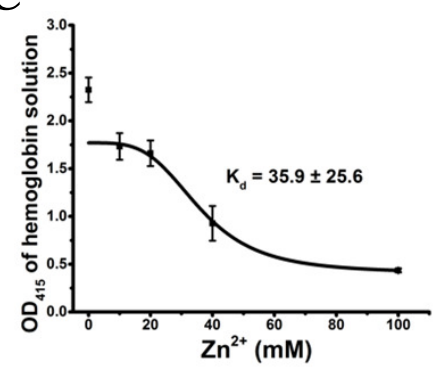

540 
542 Fig. 5. UV-Vis spectroscopy of hemoglobin solution. (A) UV-Vis spectroscopy of hemoglobin solution in 543 the presence of $\mathrm{Cu}^{2+}(30,60,120 \mu \mathrm{M})$. (B) $\mathrm{UV}-\mathrm{V}$ is spectroscopy of hemoglobin solution in the presence 544 of $\mathrm{Fe}^{2+}(20,40,120 \mathrm{mM})$.
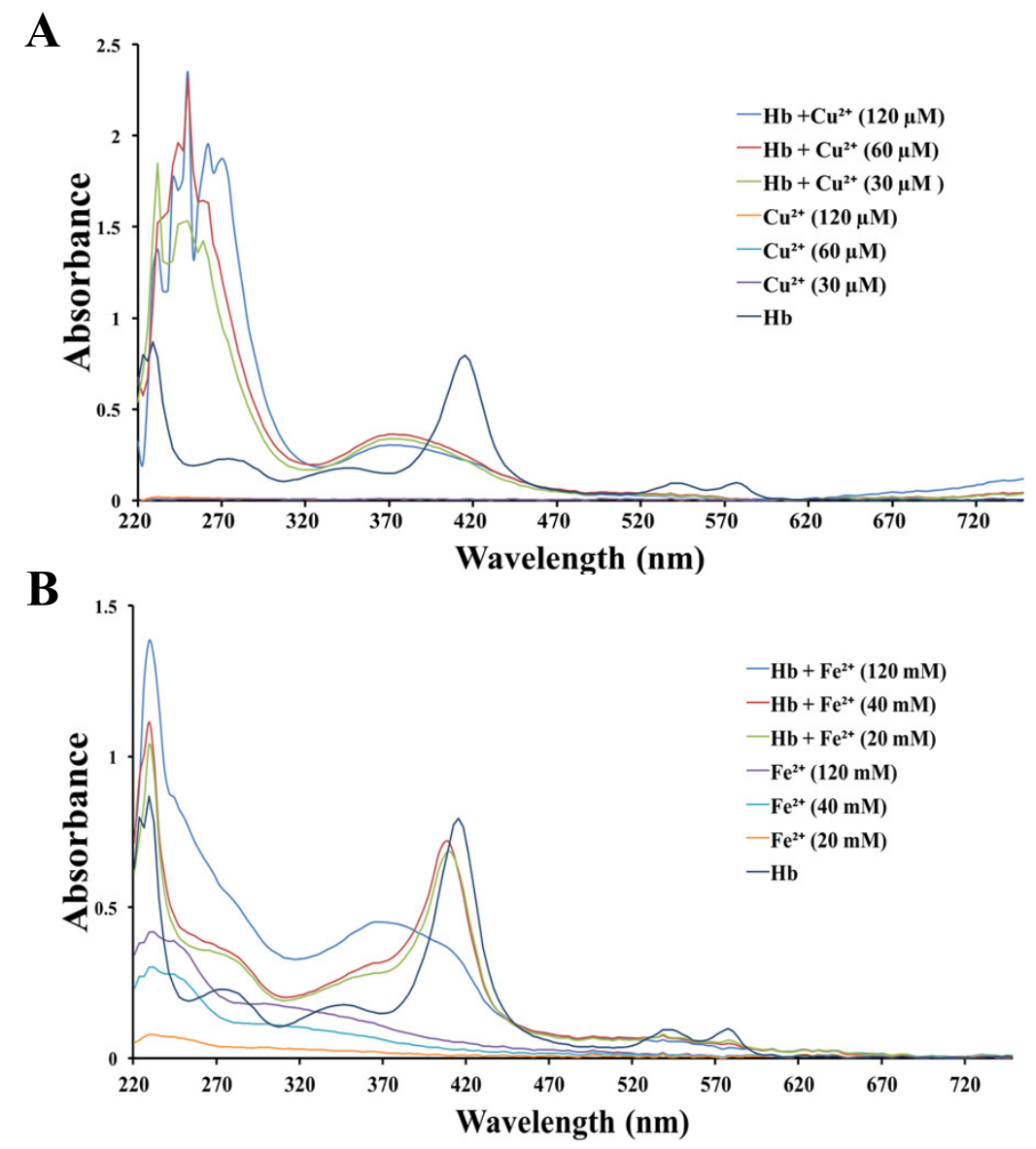

545

546 Fig. 6. Correction of cation inhibitory effects on TE-induced hemolysis. $\mathrm{La}^{3+}$ (A); $\mathrm{Mn}^{2+}(\mathrm{B}) ; \mathrm{Zn}^{2+}(\mathrm{C})$; $547 \mathrm{Cu}^{2+}(\mathrm{D})$; and $\mathrm{Fe}^{2+}(\mathrm{E})$ are displayed. The curves marked "correction" were adjusted according to the 548 equation ' $y=a x$ ', where ' $y$ ' is the real hemolytic ratio, ' $x$ ' is the determined hemolytic ratio, and ' $a$ ' is the 549 adjustment coefficient, i.e., the inverse of the ratio of cations at the corresponding concentration on the 550 absorbance values of hemoglobin. The curves marked "original" were adjusted according to the 551 determined hemolytic ratio (Fig. 2). The curves marked "Hb" were adjusted according to the $\mathrm{OD}_{415}$ of 552 cations on the released hemoglobin from a $0.45 \%$ erythrocyte suspension by spectrophotometry (Fig. 4). $553 K_{\text {d-correction }}, K_{\mathrm{d}-\text { original }}, K_{\mathrm{d}-\mathrm{Hb}}$ are all listed, respectively. Corresponding dose-response curves were depicted 554 based on Hill's co-operation analysis. All data are demonstrated as the mean $\pm \operatorname{SD}(n=3)$. 
A
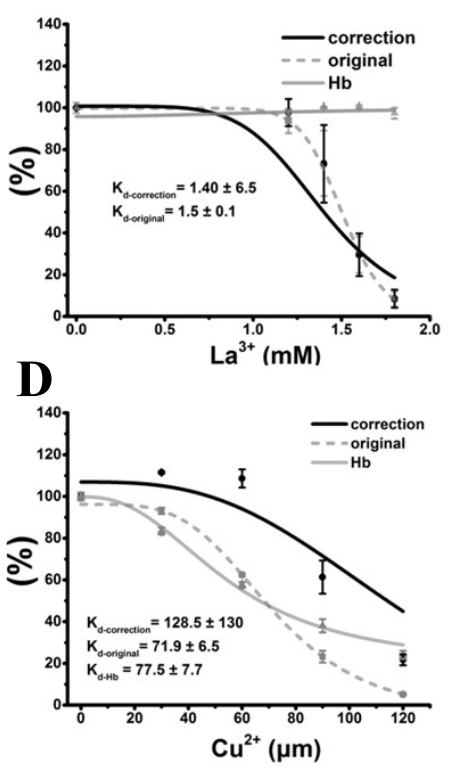

B

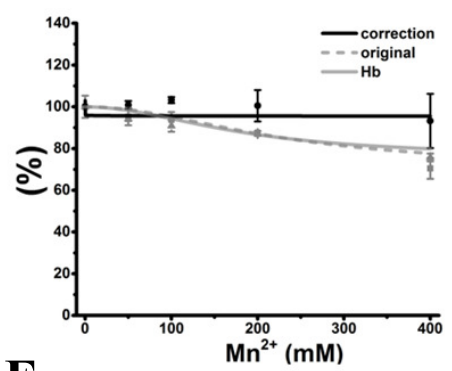

E

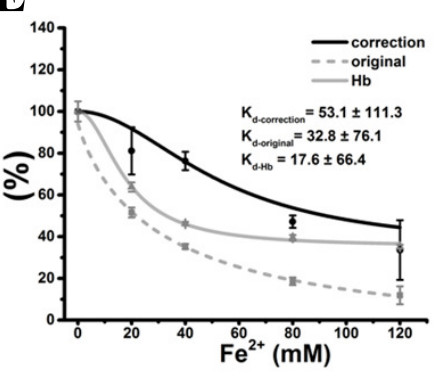

C

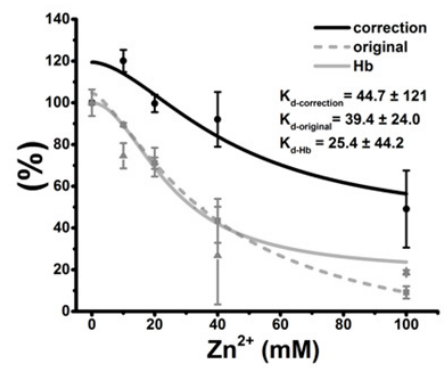

555

556

557

558

559

560

561

Fig. 7. Effects of the cations on TE-induced hemolysis by direct erythrocyte counting under microscopy using the maximal anti-hemolytic concentrations of cations $\left[\mathrm{La}^{3+}(1.8 \mathrm{mM}) ; \mathrm{Mn}^{2+}(400 \mathrm{mM}) ; \mathrm{Zn}^{2+}(100\right.$ $\left.\mathrm{mM}) ; \mathrm{Cu}^{2+}(120 \mu \mathrm{M}) ; \mathrm{Fe}^{2+}(120 \mathrm{mM})\right]$. The erythrocyte amount (\%) means the ratio of cell numbers in different cations plus TE groups versus cation-only groups. All data are demonstrated as the mean $\pm \mathrm{SD}$ $(\mathrm{n}=3) .{ }^{*} P<0.05$, compared to the TE-treatment group.

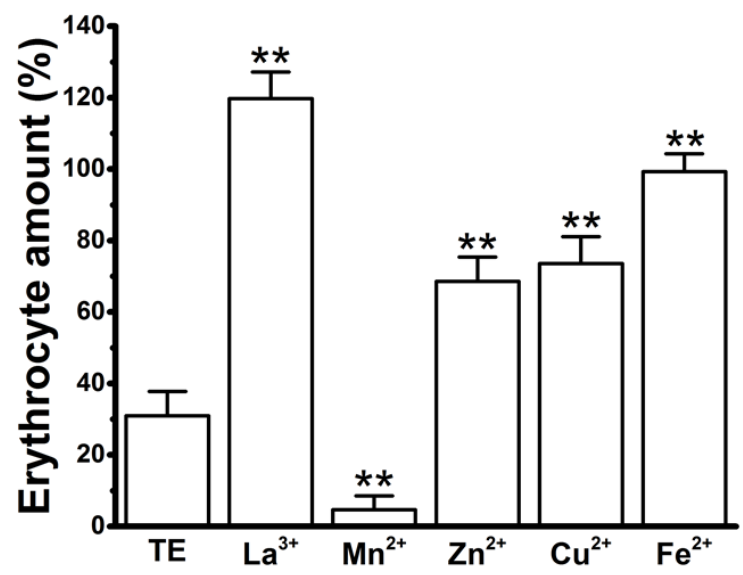

